\title{
Eros: from Hesiod's Theogony to Late Antiquity, Museum of Cycladic Art, Athens, 10th December 2009-11th April 2010
}

\author{
Eleni Vomvyla \\ UCL Institute of Archaeology
}

This review contains excerpts from an interview with Director Professor Nicholas Stampolidis, conducted at the Mueseum of Cycladic Art on January 13th 2010.

Eros: limb-loosening, bittersweet, pain inducing, merciless, sweet-tempered, allabounding, languishing, invincible, irresistible, graceful, tender. The God of Love is at the heart of this rich exhibition bringing together 272 objects, dating from sixth century $\mathrm{BC}$ to fourth century AD, sourced from fifty museums across Greece, Cyprus, Italy and France. Showcasing items from vases, pottery and jewellery to marble and terracotta groups and figurines, Eros: from Hesiod's Theogony to Late Antiquity depicts the goldenhaired god 'as he is perceived by the [ancient] Greeks' (Stampolidis and Tassoulas 2009: 1) in all his diversity: a divine figure, a human value and a daily practice.

When asked 'why an exhibition on Eros in the first place?' the director of the museum, Professor Nicholas Stampolidis asserted that 'through the millennia influential gods and goddesses, heroes and heroines may have come and gone; Eros, nevertheless, still rules people's lives.' The idea of the exhibition was conceived back in 2006 by the then Head Trustee, the late Dolly Goulandris. It took three and a half years of research and the generous sponsorship of the Niarchos and Costopoulos Foundations, for Stampolidis and curator Yorgos Tassoulas to produce the first major archaeological exhibition on the God of Love. 'The project, overall, was a challenge' according to Stampolidis, who confessed that 'it is easy to read and write about love, but it is extremely difficult to convey the image of love through an exhibition.'

Adopting a thematic arrangement, the exhibition symbolically classifies its diverse material into nine units inspired both by the nine spheres of Plato's musical theory and by the nine Muses, goddesses of literature and the arts. In the entrance hall, a text-panel with a red background introduces the visitor to the origins of the word Eros, stemming from the ancient Greek verb $\dot{\varepsilon} \rho \alpha \dot{\omega} \omega-\tilde{\omega}$ (I love, desire, lust), and to its cult in ancient Greece. Curators have traced changing perceptions of Eros from Hesiod's Theogony (c.700 BC), where he appeared as a 'primeval cosmogonic deity' springing out of Chaos, to the Roman era when, less potent and then known as Cupid, he became the mere companion of Aphrodite (Venus). From there, red arrows on the floor lead in two different directions leaving the visitor to decide where to start unfolding the god's story. 
In the Dolly Goulandris Wing of the museum, the focus is on Eros the deity. Originally the embodiment of desire in Homeric epics and the aniconic fertilising force for Hesiod, Eros becomes the son of Aphrodite in Sappho's writings and seventh century BC lyric poetry. The scenes depicting an affectionate mother-son relationship on vases, and in marble and terracotta groups and figurines, go hand in hand with those of spanking and punishment of the mischievous child for misbehaving (see figure 1).

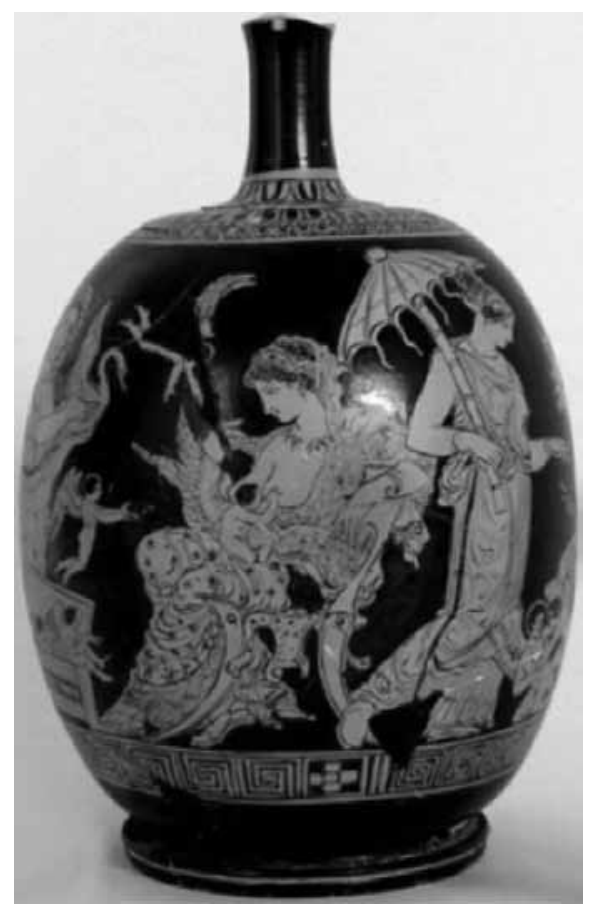

Figure 1. Aphrodite nursing Eros. Apulian red-figure squat lekythos, 360-340 BC. Taranto, National Archaeological Museum, inv. no. 4530.

Fertility deity, master of nature, archer and musician - these are but a few of the diverse 'qualities and activities' associated with the god of Love dominating the next room. Vases, terracotta figurines, marble statues, clay seals and gold earrings bear compositions of Eros holding branches of lotus flowers or fertility symbols, riding animals, playing the flute and the kithara (guitar), or indiscriminately pointing his arrows at the hearts of gods, heroes and mortals. Funerary art is present in a series of grave reliefs and marble statuettes from the Hellenistic and Roman period. The gold-winged god is pictured either asleep or leaning on an inverted torch with eyes shut to represent the spirit of the deceased. In the centre of the room, the exhibition's showpiece, Roman marble statues of Eros and Psyche (soul) about to exchange a passionate kiss, draws the visitor's attention (see figure 2). Their turbulent relationship traces its roots to Plato's Phaedrus (early fourth century BC) and enjoyed widespread popularity during the Hellenistic and Roman periods as a group of clay seals from Delos reveal. Eros appears to grab Psyche 
by the hair, spank her with a paddle, tie her hands to a column, catch her in his fishing hooks, and even to roast her over a fire.

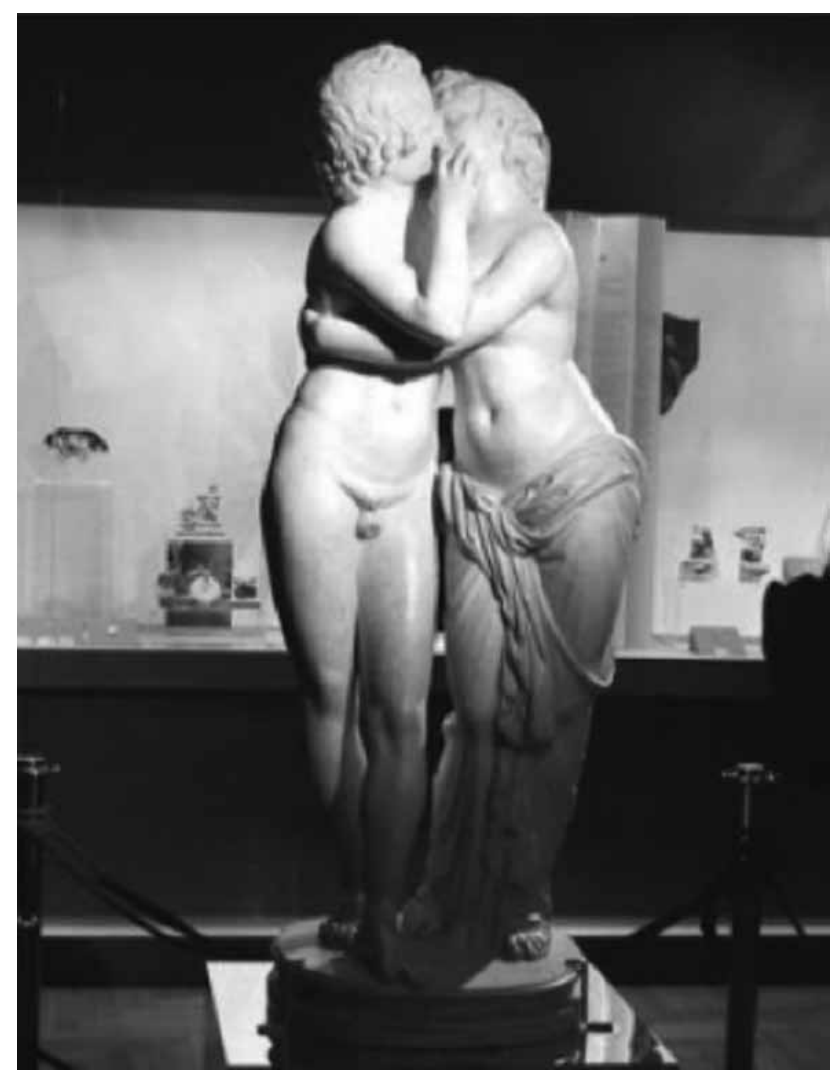

Figure 2. Eros and Psyche embracing each other. Marble group, 2nd cent. AD. Rome, Capitoline Museum, inv. no. MC 408.

Passing through a corridor visitors find themselves in the Stathatos Mansion. Here the focus is switched to the phenomenon of Eros as a human value and daily practice. On the ground floor two rooms devoted to the 'love affairs and weddings' of mortals and immortals shed light on familiar and not so familiar aspects of ancient Greek and Roman society. As a Sicilian red-figure pyxis depicts, Zeus may have committed himself to Hera, but his erotic lust for Leda, Europe and Ganymede led him into several extramarital affairs (see figure 3). Erotic desire and passion are not absent from the affairs of mortals either, as we see where a certain Arkesimos calls for his sweetheart to 'come as soon as possible' on a fifth-century BC pottery sherd from Athenian Agora. However, Stampolidis notes that 'Eros does not assume reciprocity' and this seems to be apparent in a jilted lover's curse tablet from the island of Kos. Bearing sketches of daemons and evoking magic names, the Roman lead tablet asks for the death of someone called Hermias by a feverish illness. 


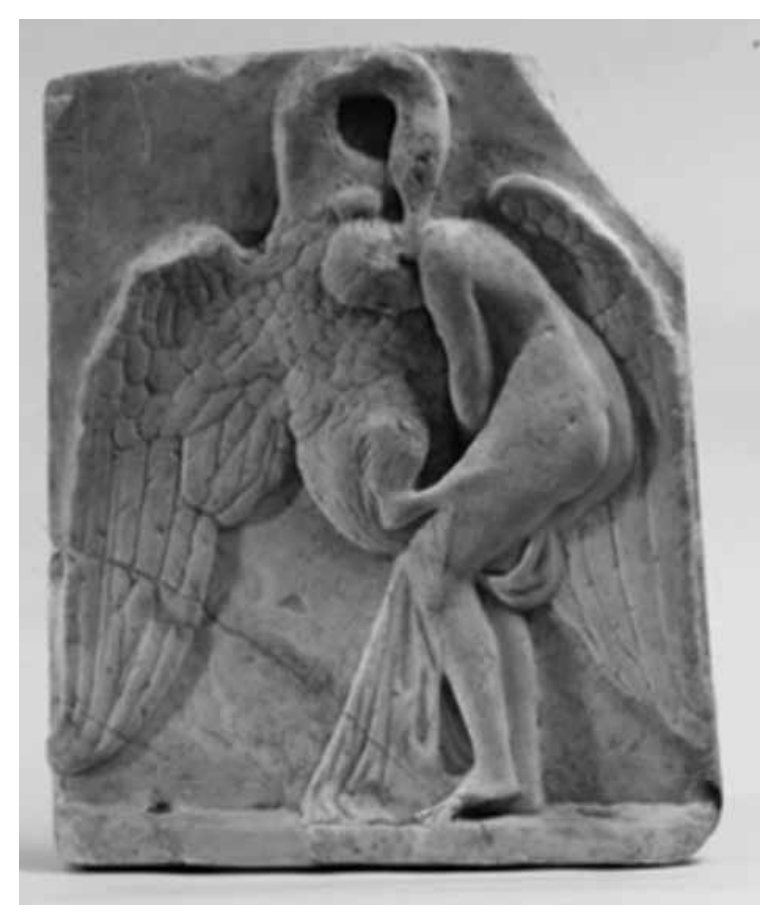

Figure 3. Zeus, transformed into a swan, immobilises Leda. Marble group, 2nd cent. AD. Athens, National Archaeological Museum, inv. no. 1499.

Weddings between mortals were rarely the outcome of erotic union or longing, the exhibition informs us. Ancient Greek society saw these rather as an agreement between the father of the bride and the groom, for the production of a legitimate offspring, preferably a boy. Vases used in nuptial rites or for female toiletry portray Eros participating in wedding preparations and thus ensuring love, tenderness and fertility for newlyweds.

In a neighbouring and primarily text-based section, the curators present the story of two couples' 'love affairs that changed the course of history.' This is the shortest thematic unit of the exhibition and my personal feeling is that it is rather questionable as to whether it fits that well with the overall concept. There are no exhibits to convey the story of the first couple, which can only capture visitor's attention through an abstract by Thucydides in the explanatory text. Three silver coins - the only exhibits involved - refer to the love affair of the second couple, that of Cleopatra VII and Mark Antony, which marked the end of the Hellenistic period in the Eastern Mediterranean.

At the beginning of the stairs leading to what has been called the 'crowd-puller' of the exhibition on the first floor (The Independent January 27th 2010), a red sign warns of the 'sexually explicit nature of the exhibits,' advising under-16-year-olds not to enter 'unattended.' This is not a matter of 'hypocritical prudency' for Stampolidis, who 
insists that 'nothing should be censored within a museum context' and does not 'see why children should learn about love only from magazines or the Internet and not through art.' He explained that the main reason for requiring youngsters to be supervised is to minimise the chances of misinterpreting the exhibits or leaving the exhibition with incorrect impressions.

Controversial or not, the exhibits upstairs have been by far the favourite part for the local and international press, provoking headlines such as 'Censorship-free ode to Eros' (Athens News, December 12th 2009); 'Laid bare: the sex life of the ancient Greeks in all its physical glory' (The Guardian, December 9th 2009); or 'The joy of sex- an ancient guide' (The Independent, January 27th 2010). Stampolidis however states explicitly that the objects on display are not there to 'shock.' He says that he and his team have tried to show things with 'honesty,' inviting visitors to see the exhibition with their eyes and minds wide open. Besides, as he continuously emphasised during our discussion,

... in ancient Greece one could see a sexual scene on a public or private building's crown tile...ancient Greeks were anything but prudes...their society was one of openness and great tolerance, lacking doctrines or guilt.

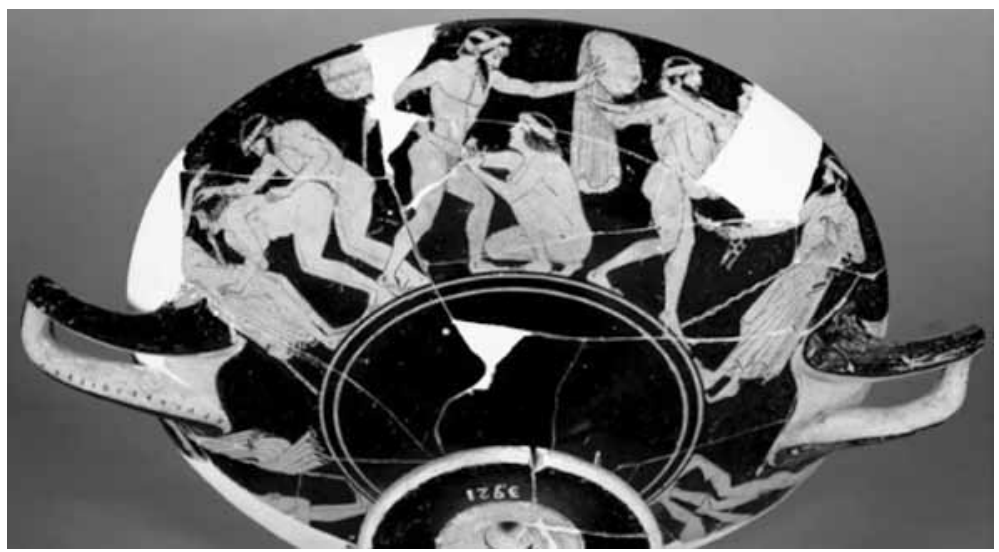

Figure 4. Scenes from a symposion. Attic red-figure kylix, 490-480 BC. Florence, National Archaeological Museum, inv. no. 3921.

Visitors' eyes are not to be shielded from 'remunerated love,' where prostitutes, their workplaces, their institutionalisation, clients and stories take the lead. From those of the lowest rank such as deikteriadai (working in inexpensive brothels), leophoroi (cheap prostitutes on the street), and khamaetypai (performing sex on the ground) to the highly paid and emancipated hetaerae playing music or dancing in symposia, and often linked to influential men, prostitutes generated a substantial part of public revenue by paying a special tax known as the pornikon telos (prostitution toll). Most commonly slaves, prostitutes were often a source of inspiration for ceramic artists during the Archaic and Classical periods. Kraters, oinohoai, and kylikes, all vases commonly used in symposia, 
feature erotic scenes in all their glory, from a tender couple's embrace to a variety of wild sexual congresses, including anal and acrobatic sex, sadism and fellatio (see figure 4). In the corner, the reconstruction of a humble brothel room (lupanar in Latin) based on a model unearthed in Pompeii (c.72 AD) introduces the visitor to the workplace of the lower paid prostitutes (see figure 5). Sexual scenes were omnipresent in brothels, appearing on a range of surfaces from wall paintings to Roman oil-lamps.

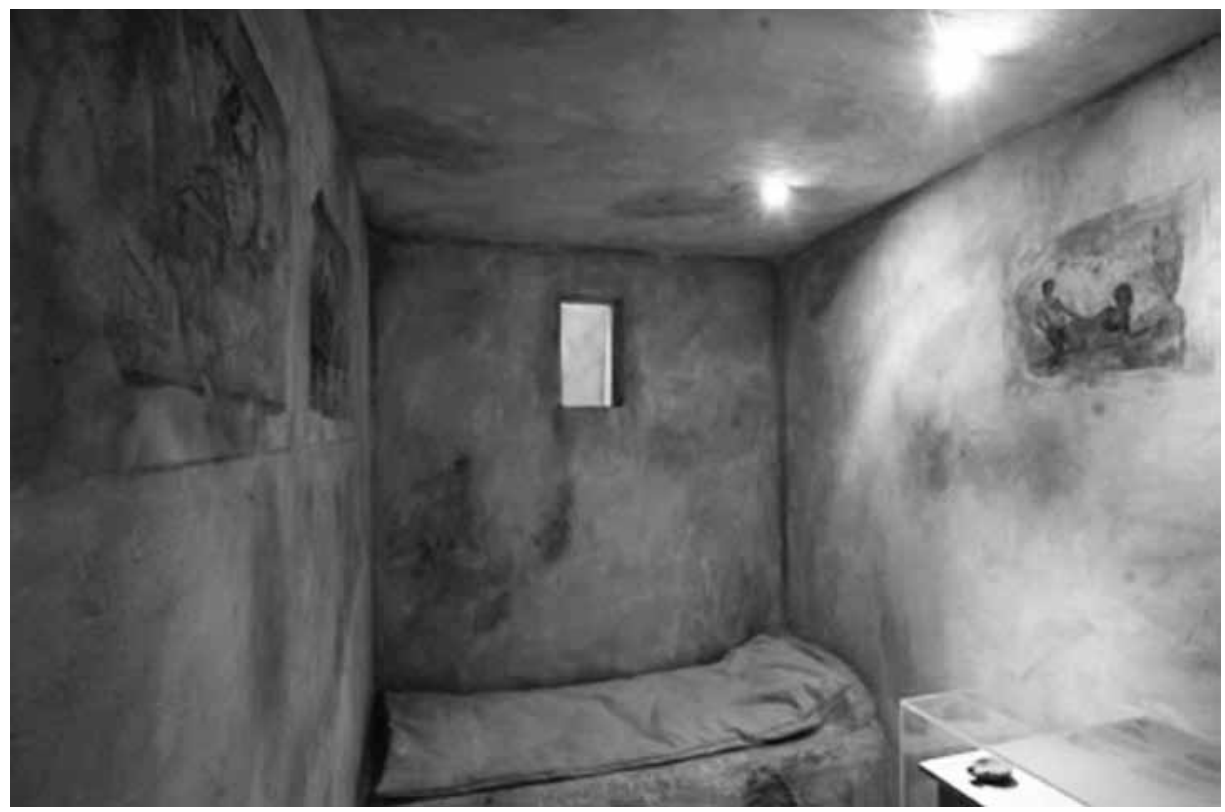

Figure 5. The reconstruction of a humble brothel room (lupanar in Latin) based on a model unearthed in Pompeii (c.72 AD).

'Homoerotic love' including pederasty follows next, which describes the pedagogic connection developed between experienced male adults, known as erastes (lovers), and adolescent boys (aged 12-to-17-years-old), known as eromenoi (beloveds). Stampolidis has been asked by many, "Why call it 'homoerotic' and not 'gay' love?" 'Because there were rules to follow,' he explains. Law permitted pederastic relationships exclusively among free citizens, whereas male prostitution was out of the question, leading to the loss of political rights for anyone caught soliciting. Unwritten rules seemed to have permeated male sexual intercourse, favouring erotic acts and positions that preserved the eromenoi's dignity. An example of this was intercrural sex (known as diamerizein) where the lovers stand face-to-face, as an attic black-figure lekythos from early fifth century $\mathrm{BC}$ depicts (see figure 6). Images of anal intercourse (known as pygizein) on the other hand, rarely appeared. The practice, featured on a sixth century BC plate in the exhibition, was considered to be humiliating for the passive partner according to ancient texts. 


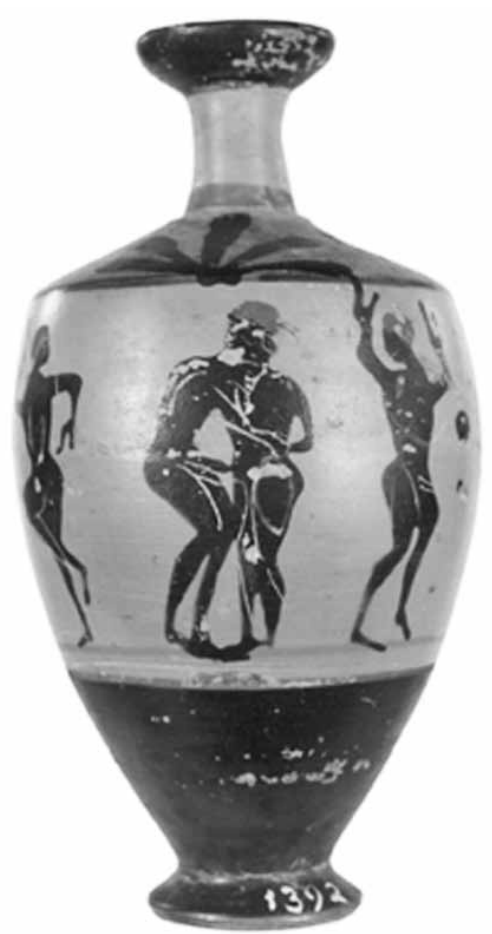

Figure 6. Intercrural intercourse between two male lovers. Attic black-figure lekythos, 500-475 BC. Civita Castellana, Museum of Agro Falisco, inv. no. 1392.

Pederasty was socially accepted in antiquity and should not be confused with contemporary practices and views. These homosexual relationships seem to have been nourished within a sociopolitical context favouring beliefs of women's inferiority, and promoting familiarity with the naked male body through the use of gymnasia and palaestrai. In ancient Greece members of the male population of all ages used to spend many hours in both locales; boys attended classes, young men exercised naked and older men engaged in conversation or caught up on the news. Palaestrai were open to any citizen, however it was mainly the aristocracy who had the free time and the financial means to offer gifts to young adolescents. From this perspective, pederasty represented a kind of a teacher-pupil relationship, where the adult prepared the youth to be a future citizen. An abstract from Anthologia Graeca on the exhibition wall declares:

I delight in the prime of a boy of twelve, but one of thirteen is much more desirable. He who is fourteen is a still sweeter flower of the Lovers and one who is just beginning his fifteenth year is yet more delightful. The sixteenth year is that of the gods, and as for the seventeenth it is not for me, but for Zeus to seek it.

Homoerotic courtship scenes become increasingly popular in Attic black-figure vase painting during the second half of the sixth century BC, including lovers fondling their 
beloveds' genitals and offering them gifts (see figure 7). After the establishment of Athenian democracy by Cleisthenes (508/7 BC) these scenes rarely appear, leading Shapiro (1981) to conclude that they probably reflected upper class preferences supporting Peisistratids' regime (an ancient Greek family that ruled tyrannically in Athens from 546 to $528 / 7 \mathrm{BC}$ ).

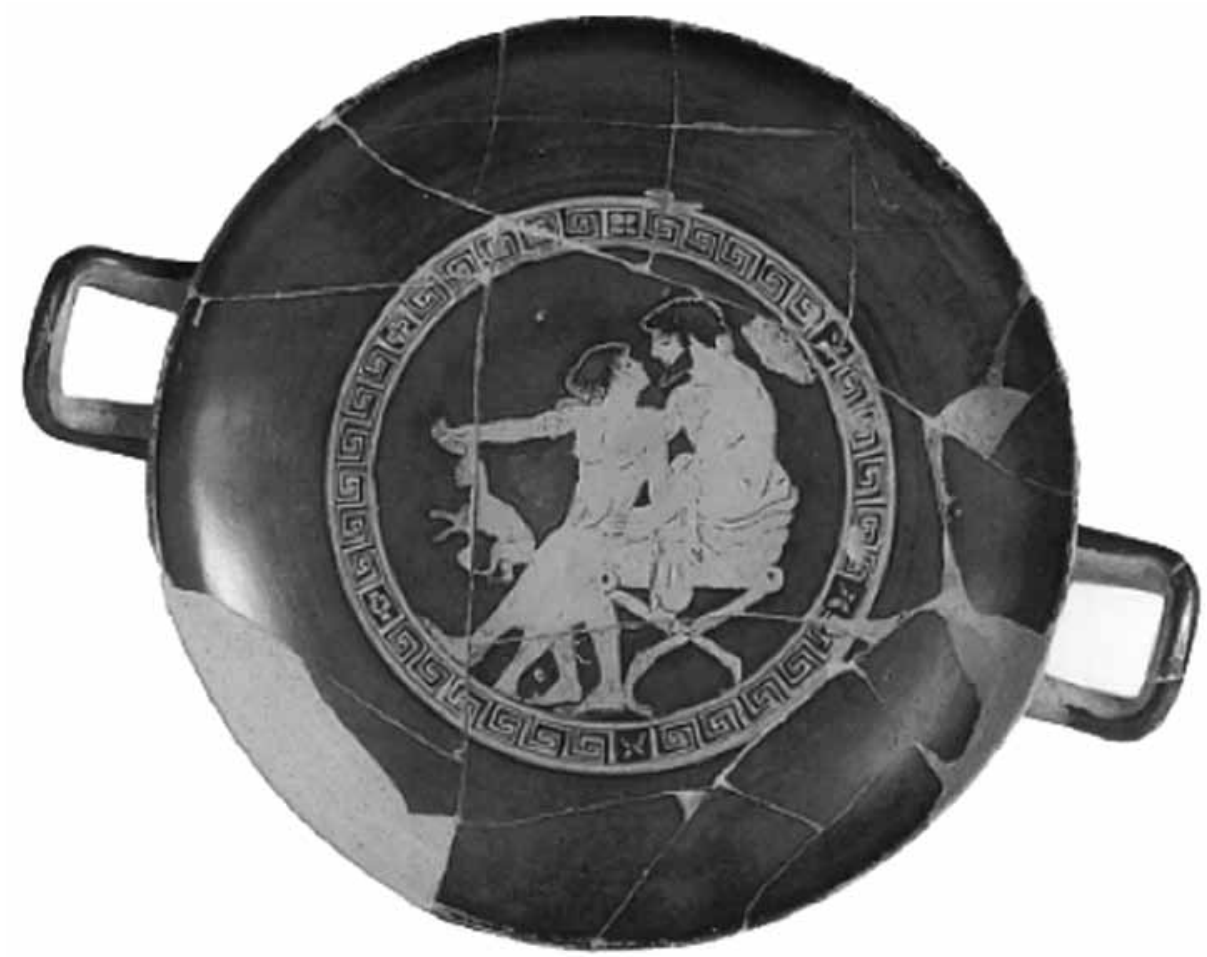

Figure 7. Offering gifts and fondling. Attic red-figure kylix, 490-470 BC. Tarquinia, National Archaeological Museum, inv. no. 701.

Things are wilder in the next room featuring bestiality scenes, or 'bucolic love affairs' as the curators call them. Men sodomize donkeys, deer and goats and women copulate with donkeys (see figure 8). Bestiality in antiquity is not to be taken for granted though. These representations might be real or could merely satirize the extraordinary sexual adventures of Dionysos' mythological entourage.

Stone and marble phalluses of all sizes, vases depicting phalluses, phallus-shaped vessels and phallic miniature pendants and amulets close the exhibition. The male reproductive organ often appears in scenes associated with fertility and merrymaking. In a mid-fifth century BC Attic red-figure kylix two hetaerae dance around a huge phallus standing on testicles, probably as part of the Haloa cult festival celebrating Dionysus (see figure 9). Invested with apotropaic and prophylactic properties throughout antiquity, stone or 
marble phalluses were to be seen in roof tiles, front doors or exterior house walls. 'This one is for me and this one is for you,' announces a marble first century BC relief from Delos bearing two zoomorphic-winged phalluses facing each other. Originally placed on the front door of a house, the rectangular plaque protected the inhabitants from envy, and promised that the owner would share all the joys of life with his visitors. Phallusshaped or phallus-bearing vases served as banquet vessels often used at symposia, whereas phallic amulets or pendants protected and brought luck to young boys who wore them around their necks.

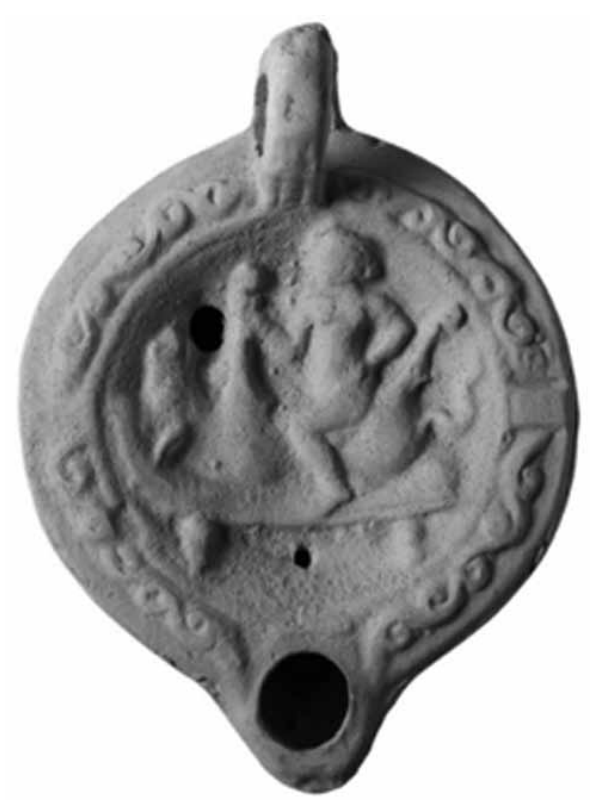

Figure 8. Woman copulating with donkey. Single-nozzle lamp, 150-250 A.D. Nicosia, Cyprus Museum, inv. no. CS1506/28.

On the whole, the exhibition made limited use of multimedia technologies, adopting more 'linguistic-based modes of interpretation' (Messham-Muir 2005: 1) with text and a variety of artefacts serving as its main forms of communication. Text panels on the wall provided detailed introductory information on each thematic unit, but were sometimes too long to read at one visit. Labelling accompanying the objects on display was placed in numerous instances in the opposite direction to them, disrupting the flow of the exhibition. A brief video summarising the key points formed a nice and efficient alternative for the visitor who could not follow the text panels in all their length and density of meanings. Abstracts on the walls from ancient Greek literature provided vivid narratives of the sociopolitical and historical context, giving life to the objects on display. The reconstruction of the small brothel room with the built-in bed in the corner triggered the visitors' imaginations, thus engaging them at a sensory level. 


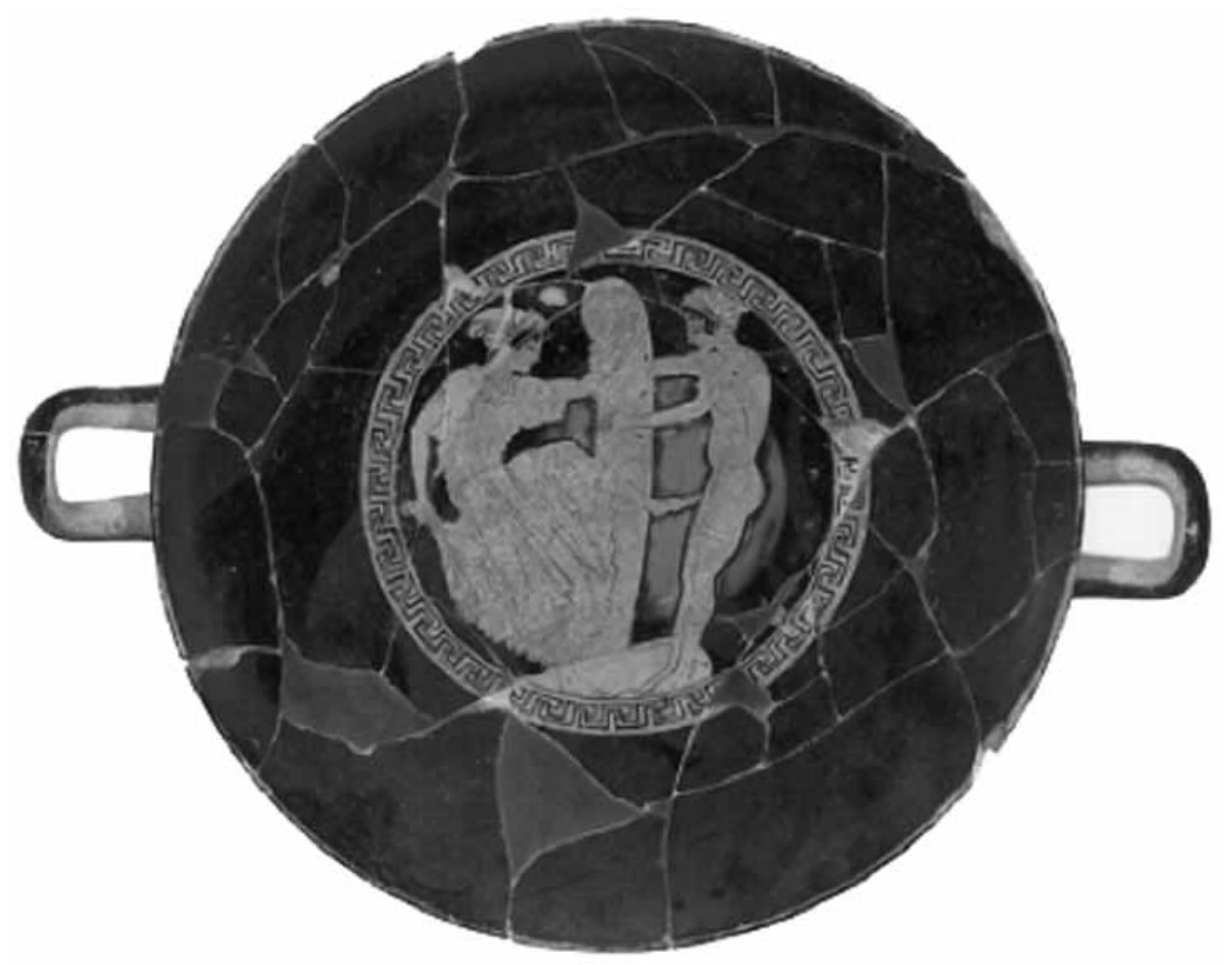

Figure 9. Hetaerae participating at Haloa festival. Attic red-figure kylix, 500-450 B.C. Rome, National Etruscan Museum of Villa Giulia, inv. no. 50404.

By bringing together a wide range of ancient objects and adopting thematic instead of linear chronological approaches, the curators have succeeded in presenting the broad concept of Eros that encompassed both sexual and sentimental dimensions. The exhibits, which seldom come out of museums' storage cabinets, unveiled human, personal and highly intimate aspects and attitudes of ancient Greek and Roman society towards their sexuality that the public rarely comes across in textbooks or traditional archaeological exhibitions. From national TV programmes to websites belonging to the Greek gay community, the universal subject of Eros seems to have attracted the public's attention, reaching out to audiences from diverse socio-cultural backgrounds. Browsing through the comments book, one is left with the impression that most visitors enjoyed the 'journey' through this underrepresented and all too often, untold story of the past. In some cases it seems to have made them write more openly about their sexuality, or feel comfortable enough to draw phalluses in it, perhaps an insult for any traditional exhibition's guest book, but not for this one.

\section{Supporting programme and material}

Visitors to the exhibition are given a free brochure including all of the introductory text provided for each thematic unit. A series of philosophy, archaeology and art-history 
seminars centred around the exhibition's theme have been presented throughout its duration. The main exhibition catalogue, a 300-page volume, is a combination of papers covering different aspects of Eros accompanied by detailed descriptions, interpretations and a bibliography for the majority of the exhibits (Stampolidis and Tassoulas 2009).

\section{References}

Athens News, 21.12.2009. Censorship-free ode to Eros. [http://www.athensnews.gr/ articles/13369/21/12/2009/24429] (Accessed on 14 July 2010).

Messham-Muir, K. 2005. Affect, Interpretation, and Technology. Open Museum Journal 7, 1-13. [archive.amol.org.au/omj/ volume 7/docs/KMessham-Muir.pdf] (Accessed on 25 March 2010).

Shapiro, H. A. 1981. Courtship scenes in Attic Vase-Painting. American Journal of Archaeology 85, 133-143.

Stampolidis and Tassoulas, Y. 2009. Eros: From Hesiod's Theogony to Late Antiquity. Exhibition brochure. Athens: Museum of Cycladic Art.
The Guardian, 9.12.2009. Laid bare: the sex life of the ancient Greeks in all its physical glory. [http://www.guardian.co.uk/ culture/2009/dec/09/museums-greece] (Accessed on 14 July 2010).

The Independent, 27.01.2010. The joy of sex - an ancient guide. [http://www. independent.co.uk/life-style/love-sex/ desire/the-joy-of-sex--an-ancientguide-1879995.html] (Accessed on 14 July 2010). 